\title{
Assessment of Fetal Attitude
}

National Cancer Institute

\section{Source}

National Cancer Institute. Assessment of Fetal Attitude. NCI Thesaurus. Code C92735.

A method to find the position of the fetal head in the uterine cavity in its descent during labor. 